\title{
The Clinical Case of a Married Hermaphrodite in a Developing Community
}

\author{
Wilson Onuigbo ${ }^{1}$ and Michael Ezenyirioha ${ }^{2}$ \\ ${ }^{I}$ Medical Foundation \& Clinic, 8 Nsukka Lane, Enugu, Nigeria \\ ${ }^{2}$ Julius Memorial Hospital, Enugu, Nigeria
}

*Corresponding Author: Wilson Onuigbo, Medical Foundation \& Clinic, 8 Nsukka Lane, Enugu, Nigeria

\begin{abstract}
The Igbo Ethnic Group occupies mainly the South Eastern Region of Nigeria. Since male inheritance is the norm, a married 38-year-old patient was taken to a Hospital by his father for the actualization of this quest. However, the report showed preponderating female elements. Therefore, social management was indicated especially in terms of providing a surrogate husband! One wonders about the epidemiological potentials of this case among indigenous people.
\end{abstract}

Keywords: Hermaphrodite, operation, female element, surrogate management, Igbos, developing community.

\section{INTRODUCTION}

Among the Igbos, a major Ethnic Group in the South-Eastern part of Nigeria (1), males are a desideratum in order to accomplish family desires regarding succession. As is practiced, the son inherits everything. Accordingly, one father was anxious to know the problem responsible for the ongoing fruitlessness of his offspring.

\section{CASE REPORT}

A 38-year-old married patient was presented at the hospital to the junior author (ME) by a parent. There were no children. However, the father preferred to have a son for the customary purpose of familial inheritance. During childhood, the breast had been enlarging and had to be removed at another hospital.

On admission, there was a small phallus. The right labium majus was enlarged. No testicle could be detected, nor was there a vaginal opening. The urethral opening was concealed. Exploratory operation was undertaken and several specimens were submitted to the senior author (WO).

There was a $6 \mathrm{~cm}$ uterus which, on section, showed some suspicion of fibroid and adenomyosis. The ovary revealed typical copora lutea and albicanta. Microscopy showed up these elements of the ovary. Clusters of endometrial glands were evident as well as some deeply within uterine tissue.

Female hermaphrodite was diagnosed firmly. Therefore, the father had to have counseling to remedy matters.

\section{DISCUSSION}

Fruitlessness was a problem in another sense. Thus, there is the "nrachi" solution, whereby an Igbo daughter is compelled to stay unmarried so that begetting a boy would be accomplished! Dr. Ikedife explained this vogue (2). Also, he touched on the gestosis (3) which he found to be associated with it.

On my part, I noted similar publications in UK (4) and USA (5). Indeed, as I reported recently (6), outside help should be sought to solve this issue. In this context, I advanced the view that allied health professionals should be involved in solving the problem.

Accordingly, concerning the particular case on hand, it seems to me that obtaining a surrogate husband would be the socially acceptable solution! In this context, as a matter of general interest, what is the picture worldwide, especially among indigenous peoples?

\section{REFERENCES}

[1] Basden GT. Niger Ibos. Cass, London 1966. 
The Clinical Case of a Married Hermaphrodite in a Developing Community

[2] Ikedife D. Eclampsia in multipara. Br Med J, 1980; 280:985-986.

[3] Feeney JG, Scott JS. Pre-eclampsia and changed paternity. Eur J Obstet Gynecol Reprod Bio, 1980; 11:35-38.

[4] Marx GP, Habib NS, Schulman H. is preeclampsia a disease of the sexually active gravid? Med Hypotheses, 1981; 7:1397-1399.
[5] Chappll L. Editorial. Recent advances in preeclampsia and eclampsia. Trop Doctor 2004; $34: 1$.

[6] Onuigbo WIB. Can allied health care professionals assist obstetricians in preventing gestosis and promoting safe childbirth? Res Chron Health Sci, 2016; 2(4): 280-282.

Citation: Wilson O, Michael E. The Clinical Case of A Married Hermaphrodite in a Developing Community. International Journal of Research Studies in Medical and Health Sciences. 2017;2(4):17-18.

Copyright: (C) 2017 Wilson O \& Michael E. This is an open-access article distributed under the terms of the Creative Commons Attribution License, which permits unrestricted use, distribution, and reproduction in any medium, provided the original author and source are credited. 